\title{
Local Aggregate in Production of Concrete Mix in Jordan
}

\author{
Mohmd Sarireh*, Hamadallah Al-Baijat \\ Civil Engineering Department, Faculty of Engineering, Tafila Technical University, Tafila, Jordan \\ Email: ^m.sarireh@gmail.com, Albaijath@yahoo.com
}

How to cite this paper: Sarireh, M. and Al-Baijat, H. (2019) Local Aggregate in Production of Concrete Mix in Jordan. Open Journal of Civil Engineering, 9, 81-94. https://doi.org/10.4236/ojce.2019.92006

Received: March 1, 2019

Accepted: April 22, 2019

Published: April 25, 2019

Copyright $\odot 2019$ by author(s) and Scientific Research Publishing Inc. This work is licensed under the Creative Commons Attribution International License (CC BY 4.0).

http://creativecommons.org/licenses/by/4.0/

\begin{abstract}
Concrete properties such as unit weight and compressive strength are highly dependable on the properties of aggregate. Current research aims to study the effect of aggregate properties on concrete considering the resource of aggregate. The properties of aggregate and fine sand were studied (specific gravity, density, absorption, and abrasion). Also, the properties of concrete were studied (density, unit weight, and compressive strength). Samples of coarse and medium aggregates, and fine sand were collected from different areas in Jordan (Ajloun, Amman, Aqaba, Irbid, Jerash, Karak, Ma'an, Madaba, Salt, Zarqa, and Tafila) to be tested and used in concrete mix. Aggregate from South of Jordan has higher values in specific gravity and bulk density (Aqaba, Ma'an, and Karak aggregates). Also, the same aggregate samples have lower values in absorption and abrasion (Ma'an, Aqaba, Karak, and Tafila). For the properties of concrete that include density, unit weight, and compressive strength, all samples have achieved the design properties and strength in the current study. For density and unit weight, samples from South of Jordan have higher values (Ma'an and Aqaba). And for compressive strength, Ma'an, Irbid and Amman concrete samples have the highest values at 7-day, while the 28-day compressive strength comes highest for Zarqa, Ma'an, Irbid and Amman. From the results of the current study, the compressive strength at 7-day and 28-day is related to the density of coarse and medium aggregate, abrasion, and absorption. The higher the density, the higher the compressive strength. And the lower abrasion and absorption, the higher the compressive strength of concrete. Current research will be useful in selecting the source of aggregate to produce a considerable concrete strength.
\end{abstract}

\section{Keywords}

Aggregate, Concrete, Mix Production, Compressive Strength, Concrete Age 


\section{Introduction}

Recently, production and utilization of concrete are rapidly increasing, which results in increased consumption of natural aggregate as the largest concrete component. For example, two billion tons of aggregate are produced each year in the United States. Production is expected to increase to more than 2.5 billion tons per year by the year 2020 [1]. Also, Ghasemiin [2] pointed out that concrete is the most used man-made material in the world. So, it is important to understand and describe the properties of the material constituents, the type and proportions to make the required design through the particle packing theory and the excess water/paste layer theories. And the packing density models of particles are required in mix design, in addition to the surface area model for particles that based on the particle size distribution curves. In addition, water/cement ratio is another affecting factor in concrete compression strength and other parameters of fresh and hardened concrete: slump value, concrete flexural strength and tension. Particle density and particle size distribution have great effects on fresh and hardened concrete properties. The concept of particle packing density was introduced first in 1982 to minimize the inter-particle voids between constituents of the concrete to reduce the paste demand, while the particle size distribution was introduced earlier in 1907 and 1930.

Coarse aggregate of crushed limestone and fine aggregate of natural sand have a noticed effect on concrete strength [3]. Crushed stone of different resources can change in concrete strength and properties. And these resources represent the typical source of production through the aggregate mining, construction industry and typical usage in concrete production locally. The maximum size of aggregate and the bore structure and absorption also have an effect on concrete mix properties especially compressive strength and density [4]. According to (Alexander and Mindess) in [5], grading affects the description of fine constituents in the mix, properties of fresh concrete state, void content, water demand, and available specific area of the particles.

And as mentioned by Kwan and Mora [6], the increase in packing density of the aggregate doesn't increase the workability of the concrete mixture, even it is the way for optimum voids in the concrete mix and the aim to make a workable mixture of the concrete paste [7].

The workability of concrete is governed by the inherent properties of the constituents, proportioning and the way the constituents are interacting with each other physically and chemically. Particle-matrix model (PMM) considers concretes in two separate phases, fluid material and a friction material. Based on this logic the matrix is considered as all of the particles less than $0.125 \mathrm{~mm}$ including cement, fines and possible chemical additives while the particle phase is defined as all of the particles larger than $0.125 \mathrm{~mm}$. The model is particularly suitable for mixes where matrix phase is dominant e.g., self-compacting and high performance concrete [8] to improve workability of white concrete mix through controlling target slump, segregation and bleeding using the matrix model of the 
concrete mix proportions that include the amount of aggregate, binders and mixing water, and super plasticizer. Slump and compressive strength were carried to examine, control and enhance the required properties and performance of concrete. Reknes in [9] used the water reducer agent in self-compacting concrete to increase the plastic viscosity of the concrete by using rheology modifying admixture at different admixtures and ratios or by using the addition of fines in the concrete mix at different ratios. Workability was evaluated by the slump and the spread of concrete. Also, segregation and bleeding were noticed, if not existed, then the concrete mix is suitable to be used. The main difficulty here is to define the properties of the phases and to model the effect of these phases on each other. The basic concept of the model is shown in Figure 1 that shows the relation workability and properties of particles and matrix properties.

The approach relies on single parameter characterization of each phase [8] and [11]:

- The flow resistance ratio of the matrix.

- The air voids modulus of the particles.

Construction using local materials in concrete mixes is a priority for city administration and contractors and subcontractors in the construction sector. Also, for sustainability of resources and for traffic and road systems, it's more preferable to use local nearby materials rather than using materials from outside area. The use for far travelled materials will push for damaging road systems more rapidly, and will add a new additional cost for construction that will not be affordable by the communes. According to Shaker et al. in [3] typically local coarse aggregate and fine sand of natural resources in Egypt were used in studying properties of concrete incorporating locally produced Portland limestone cement. The coarse aggregate has $20 \mathrm{~mm}$ maximum size, specific gravity and absorption were $2.67 \%$ and $1.1 \%$. The fine natural sand has a fineness modulus of 2.74, specific gravity of 2.58, and maximum size of $5 \mathrm{~mm}$. Then, 3 mixes were prepared using the Portland Cement on 3 different ratios of limestone. Fresh and hardened properties of concrete were tested in the research. Water cement ratios were $0.7,0.6$ and 0.525 for cement contents of 300,350 and $400 \mathrm{~kg} / \mathrm{m}^{3}$, respectively on fixed free water content of $210 \mathrm{~kg} / \mathrm{m}^{3}$. Tests for concrete include

Amount of matrix

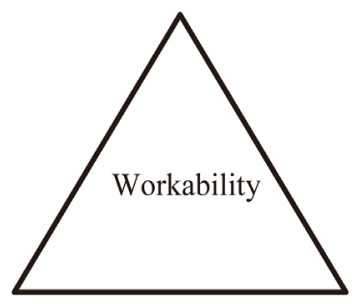

Particle properties Matrix properties

Figure 1. Particle matrix model concept to concrete [10]. 
slump, penetration resistance, compressive strength, splitting tensile strength, (modulus of rupture) flexural strength, and bond strength, in addition to the durability performance tests that include water penetration depth, sulfate resistance, and rapid chloride penetration tests.

\section{Basic Properties of Local Sustainable Concrete Aggregate (LSCA)}

The physical and mechanical properties of aggregate and concrete mix are the keys for the decision to use the wide range of difference in types of aggregates. And the comparison will be conducted between all samples of natural aggregates, but from different areas of Jordan. Samples were collected from residential site and projects during construction on Summer and Springin the year 2017. In another field of construction, hemp concrete (hemp Crete) construction, the use of different resources in origin and properties make concrete more durable and bio-beneficial that absorbs $\mathrm{CO}_{2}$ from atmosphere [12]

The variations in the physical properties of aggregates and in the mechanical properties of hardened concrete give a wide range for the application of specifications and standards of materials and testing. Also, the difference in aggregate resources gives integrity and complementary to work against resource depletion, and support sustainability. All tests conducted will be presented in this section.

Based on available experimental work that was completed, the samples of aggregates were tested for specific gravity and absorption according to the standards and specifications in [13] [14] [15] [16] [17], sieve analysis [18] [19] [20]. Then work was continued for preparing concrete mixes and samples at $20 \mathrm{Mpa}$ grade for every type of aggregate specific for each region in Jordan. Samples that were prepared, then were tested at 7 and 28 days by crushing test to determine the compressive strength of concrete [21] and density of concrete [22]. It is expected that concrete strength will develop with time as represented in Figure 2.

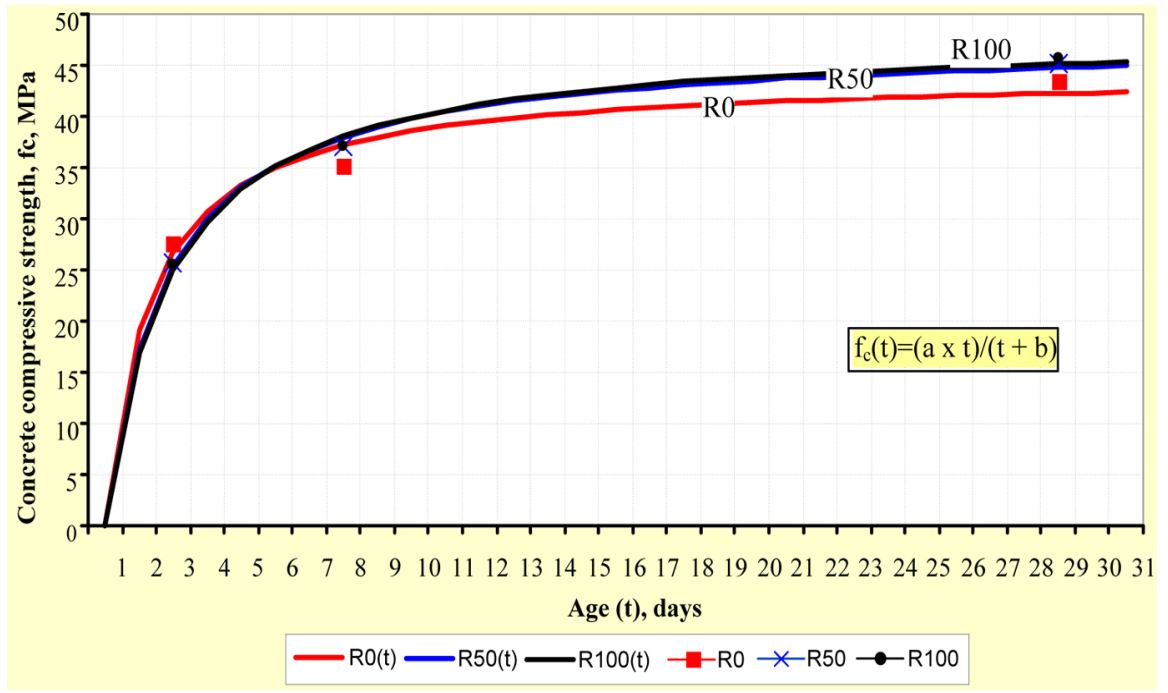

Figure 2. The compressive strength of concrete on various ages. R0: zero-recycled aggregate, R50: 50\% recycled aggregate, and R100: 100\% recycled aggregate [23]. 
Also, concrete density $\left(\mathrm{kg} / \mathrm{m}^{3}\right)$ and compressive strength $\left(\mathrm{N} / \mathrm{mm}^{2}\right)$ are functions of time, and both get developed by time. Table 1 represents these parameters for the hardened concrete at 7, 14, and 28 days. Also, testing upon time is employed by AL-jabri et al. in [24] by testing high compressive strength concrete using samples of cubes, cylinders and prisms, all samples were tested at a 7-day curing and at 28-day curing.

\section{Materials}

1) Coarse Aggregate: that has the size distribution in the range of (20 - 10 $\mathrm{mm})$ was transferred from local residential construction in the eleven areas in Jordan [25] [26]. Table 2 presents the properties of coarse aggregate.

2) Medium aggregate: that has the size distribution of (14 - $5 \mathrm{~mm}$ ), also provided for local residential construction from the eleven areas in Jordan [27]. Table 3 presents the properties of medium aggregate.

3) Fine sand: fine sand that was used in all samples of the mix of size gradation of $(2.36 \mathrm{~mm}-0.3 \mathrm{~mm})$ of natural sand [28]. Table 4 presents the properties of fine sand.

4) Cement: the Ordinary Portland Cement was used in mixing of all samples.

5) Mixing Water: is the tap water that is usually taken to be used in the mix depending on the w/c ratio. Figure 3 represents the approximate relation between the 28-day compressive strength and water to cement ratio.

Table 1. Density and compressive strength of concrete with time (day) [24].

\begin{tabular}{ccc}
\hline Time (Day) & Density of Concrete $\left(\mathrm{kg} / \mathrm{m}^{3}\right)$ & Compressive $\left(\mathrm{N} / \mathrm{mm}^{2}\right)$ \\
\hline 7 & 2351 & 16.2 \\
14 & 2376 & 21.1 \\
28 & 2402 & 25 \\
\hline
\end{tabular}

Table 2. Properties of coarse aggregate collected from Jordan for eleven areas.

\begin{tabular}{ccccccc}
\hline $\begin{array}{c}\text { Aggregate } \\
\text { Source }\end{array}$ & $\begin{array}{c}\text { Sp. Gr. } \\
\text { (Dry) }\end{array}$ & $\begin{array}{c}\text { Sp. Gr. } \\
(\text { SSD })\end{array}$ & $\begin{array}{c}\text { Sp. Gr. } \\
(\text { App })\end{array}$ & $\begin{array}{c}\text { Bulk } \\
\text { Density }\end{array}$ & Absorption & Abrasion \\
\hline Ajloun & 2.644 & 2.665 & 2.693 & 1594 & 0.024 & 0.26 \\
Amman & 2.536 & 2.595 & 2.696 & 1570 & 0.00231 & 0.31 \\
Aqaba & 2.659 & 2.709 & 2.791 & 1600 & 0.012 & 0.24 \\
Irbid & 2.617 & 2.67 & 2.755 & 1578 & 0.008 & 0.27 \\
Jerash & 2.612 & 2.643 & 2.675 & 1445 & 0.035 & 0.35 \\
Karak & 2.645 & 2.663 & 2.674 & 1580 & 0.023 & 0.26 \\
Ma'an & 2.689 & 2.699 & 2.709 & 1596 & 0.02 & 0.27 \\
Madaba & 2.498 & 2.523 & 2.548 & 1610 & 0.01 & 0.29 \\
Salt & 2.536 & 2.597 & 2.701 & 1560 & 0.024 & 0.25 \\
Tafila & 2.506 & 2.556 & 2.638 & 1500 & 0.02 & 0.29 \\
Zarqa & 2.53 & 2.591 & 2.694 & 1549 & 0.024 & 0.33 \\
\hline
\end{tabular}


Table 3. Properties of medium aggregate collected from Jordan for eleven areas.

\begin{tabular}{ccccccc}
\hline $\begin{array}{c}\text { Aggregate } \\
\text { Source }\end{array}$ & $\begin{array}{c}\text { Sp. Gr. } \\
(\text { Dry })\end{array}$ & $\begin{array}{c}\text { Sp. Gr. } \\
(\text { SSD })\end{array}$ & $\begin{array}{c}\text { Sp. Gr. } \\
(\text { App })\end{array}$ & $\begin{array}{c}\text { Bulk } \\
\text { Density }\end{array}$ & Absorption & Abrasion \\
\hline Ajloun & 2.665 & 2.672 & 2.694 & 1610 & 0.027 & 0.27 \\
Amman & 2.524 & 2.59 & 2.702 & 1577 & 0.026 & 0.31 \\
Aqaba & 2.637 & 2.699 & 2.802 & 1600 & 0.015 & 0.24 \\
Irbid & 2.69 & 2.67 & 2.778 & 1584 & 0.008 & 0.27 \\
Jerash & 2.607 & 2.628 & 2.646 & 1468 & 0.038 & 0.37 \\
Karak & 2.664 & 2.683 & 2.694 & 1597 & 0.024 & 0.275 \\
Ma’an & 2.699 & 2.678 & 2.709 & 1610 & 0.023 & 0.27 \\
Madaba & 2.501 & 2.526 & 2.612 & 1617 & 0.012 & 0.29 \\
Salt & 2.544 & 2.608 & 2.717 & 1565 & 0.025 & 0.27 \\
Tafila & 2.566 & 2.546 & 2.649 & 1500 & 0.025 & 0.29 \\
Zarqa & 2.518 & 2.585 & 2.699 & 1554 & 0.027 & 0.33 \\
\hline
\end{tabular}

Table 4. Properties of fine sand.

\begin{tabular}{cccccc}
\hline $\begin{array}{c}\text { Aggregate } \\
\text { Source }\end{array}$ & $\begin{array}{c}\text { Sp. Gr. } \\
(\text { Dry })\end{array}$ & $\begin{array}{c}\text { Sp. Gr. } \\
(\text { SSD })\end{array}$ & $\begin{array}{c}\text { Sp. Gr. } \\
(\text { App })\end{array}$ & $\begin{array}{c}\text { Bulk } \\
\text { Density }\end{array}$ & Absorption \\
\hline Ajloun & 2.684 & 2.695 & 2.72 & 1605 & 0.024 \\
Amman & 2.496 & 2.578 & 2.719 & 1569 & 0.033 \\
Aqaba & 2.636 & 2.644 & 2.66 & 1620 & 0.004 \\
Irbid & 2.618 & 2.632 & 2.653 & 1557 & 0.0152 \\
Jerash & 2.643 & 2.654 & 2.685 & 1552 & 0.019 \\
Karak & 2.672 & 2.687 & 2.695 & 1574 & 0.018 \\
Ma'an & 2.618 & 2.623 & 2.554 & 1620 & 0.008 \\
Madaba & 2.59 & 2.616 & 2.744 & 1573 & 0.002 \\
Salt & 2.489 & 2.6 & 2.72 & 1581 & 0.033 \\
Tafila & 2.616 & 2.629 & 2.65 & 1577 & 0.005 \\
Zarqa & 2.471 & 2.57 & 2.742 & 1585 & 0.04 \\
\hline
\end{tabular}

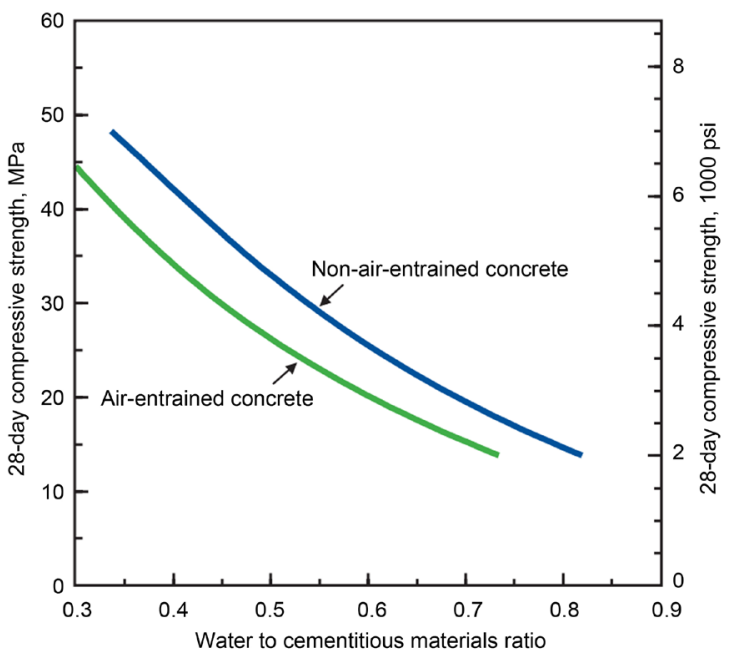

Figure 3. The approximate relation between compressive strength and W/C ratio [29]. 


\section{Mix Design and Operation}

\subsection{Collection of Samples}

Samples of aggregate were collected and provided from the main areas and cities in Jordan (Ajloun, Amman, Aqaba, Irbid, Jerash, Karak, Ma'an, Madaba, Salt, Tafila, and Zarqa). Fine sand was provided for all similar areas for concrete mixes. Concrete mix was prepared to consider $20 \mathrm{Mpa}$ concrete grade that based on a w/c ratio of 0.54 and cement content of $280 \mathrm{~kg} / \mathrm{m}^{3}$. Table 5 represents the concrete mix portions [30].

\subsection{Preparation of Samples}

Aggregate proportions were selected from natural crushed limestone that typically used in Jordan from different construction, residential sites in the selected 11 areas. Then testing samples include cubes $(150 \mathrm{~mm})$ were prepared for each mix on the proportions represented in Table 5.

\subsection{Preparations of Fresh Concrete Samples}

Samples of concrete were prepared by casting on 3 layers in the $150 \mathrm{~mm}$ cube molds according to the BS EN 12390-1 [30].

\subsection{Curing of Samples}

Full moisture curing (in $18 \mathrm{c}$ temperature) tank is used for concrete samples after casting in order to be tested for concrete density and strength at 7 and 28 days [30].

\subsection{Testing of Concrete Samples}

Cube samples were tested at 7 and 28 days for density and strength. The results obtained were compared [30] [31]. And according to BS-EN12390-3, no specified compressive strength should be less than $17.5 \mathrm{MPa}$. And that no individual average test value should $3.5 \mathrm{MPa}$ less than the specified compressive strength.

\section{Results}

The main results of the current research are the density $\left(\mathrm{kg} / \mathrm{m}^{3}\right)$ and unit weight $\left(\mathrm{KN} / \mathrm{m}^{3}\right)$ of hardened concrete and its specified compressive strength (MPa). Figure 4 presents the density of concrete $\left(\mathrm{kg} / \mathrm{m}^{3}\right)$ for the governorates' concrete mix. The density of the concrete is the highest for the Aqaba area (2450.5 $\left.\mathrm{kg} / \mathrm{m}^{3}\right)$, then Ma'an area $\left(2363.21 \mathrm{~kg} / \mathrm{m}^{3}\right)$ and Irbid area $\left(2357.8 \mathrm{~kg} / \mathrm{m}^{3}\right)$. And the

Table 5. Concrete mix portions for $20 \mathrm{Mpa}$ concrete grade [30].

\begin{tabular}{cccccc}
\hline $\begin{array}{c}\text { Coarse } \\
\text { Aggregate }(\mathrm{kg})\end{array}$ & $\begin{array}{c}\text { Medium } \\
\text { Aggregate }(\mathrm{kg})\end{array}$ & $\begin{array}{c}\text { Fine Sand } \\
(\mathrm{kg})\end{array}$ & $\begin{array}{c}\text { Cement } \\
(\mathrm{kg})\end{array}$ & $\begin{array}{c}\text { Water } \\
(\mathrm{Ltr})\end{array}$ & w/c \\
\hline 565 & 622 & 715 & 280 & 150 & 0.54 \\
\hline
\end{tabular}




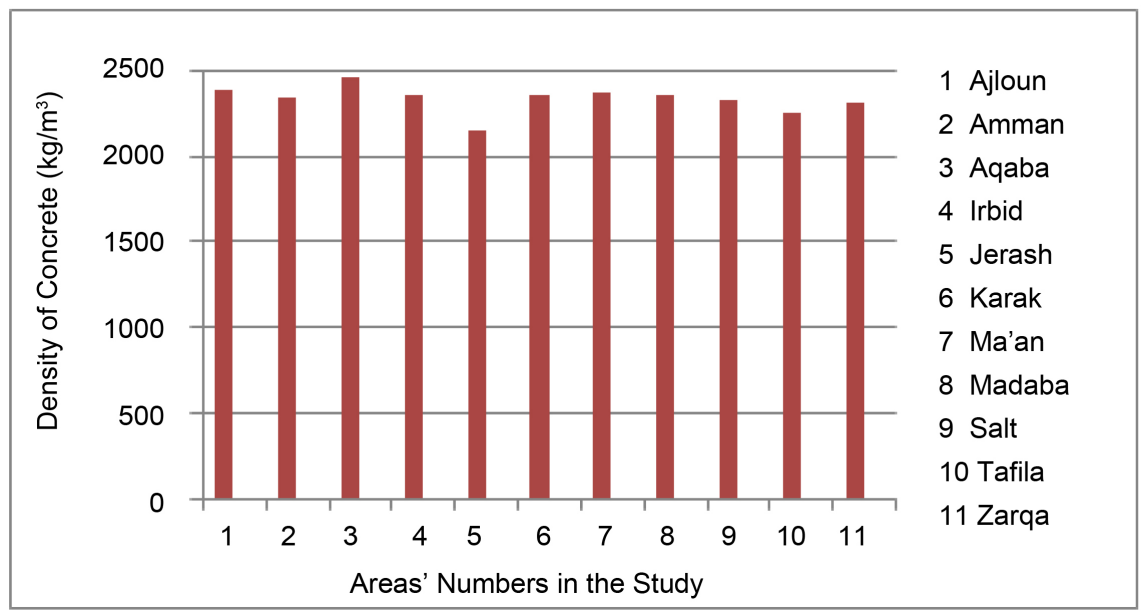

Figure 4. Density of concrete for areas of aggregate in Jordan.

lower value of the concrete density is from the Jerash area $\left(2148.14 \mathrm{~kg} / \mathrm{m}^{3}\right)$.

Figure 5 presents the unit weight of concrete for the aggregate of areas in Jordan. It is obvious that the aggregate of Aqaba has the greater unit weight $\left(24.04 \mathrm{kN} / \mathrm{m}^{3}\right)$, then $\mathrm{Ma}$ 'an concrete has $\left(23.18 \mathrm{kN} / \mathrm{m}^{3}\right)$, and Irbid aggregate has $\left(23.13 \mathrm{kN} / \mathrm{m}^{3}\right)$. And the lowest value comes from the Jerash concrete of (21.07 $\left.\mathrm{kN} / \mathrm{m}^{3}\right)$.

Figure 6 presents the 7-Day compressive strength of concrete [32] [33] that was made using aggregates from different governorates area in Jordan. Aggregate from $\mathrm{Ma}$ 'an has the highest value of 7-day compressive strength (17.42 $\left.\mathrm{N} / \mathrm{mm}^{2}\right)$, then aggregate from Irbid area comes second $\left(17.04 \mathrm{~N} / \mathrm{mm}^{2}\right)$, and aggregate from Amman area comes third $\left(16.85 \mathrm{~N} / \mathrm{m}^{2}\right)$. The lowest value of 7 -day comes from Madaba aggregate of $\left(13.13 \mathrm{~N} / \mathrm{mm}^{2}\right)$.

Figure 7 presents the 28-day compressive strength of concrete [32] [33] that was made of aggregates from the areas in the study. Aggregate from Zarqa has the highest 28-day compressive strength $\left(26.09 \mathrm{~N} / \mathrm{mm}^{2}\right)$, and Ma'an aggregate comes second $\left(25.62 \mathrm{~N} / \mathrm{mm}^{2}\right)$, and Irbid aggregate comes third $\left(25.47 \mathrm{~N} / \mathrm{mm}^{2}\right)$. And the lowest value of 28-day compressive strength comes from the Tafila aggregate $\left(21 \mathrm{~N} / \mathrm{mm}^{2}\right)$.

Figure 8 presents the compressive strength of concrete at 7- and 28-day versus the density of concrete. It is clear that the trend of compressive strength at 7-day and 28-day is the same at both versus the density of concrete. And the samples are representative of normal weight concrete.

Also, Figure 9 and Figure 10 present the relation of compressive strength at 7- and 28-day versus the bulk density of coarse and medium aggregate. It's clear that the compressive strength has similar trend on bulk density of coarse and medium aggregate. And the trend will be enough clear if the aggregate will be of the same resource or stockpile.

Also, Figure 11 and Figure 12 present compressive strength of concrete on a 7-day and 28-day considering the abrasion value for coarse and medium aggregate 


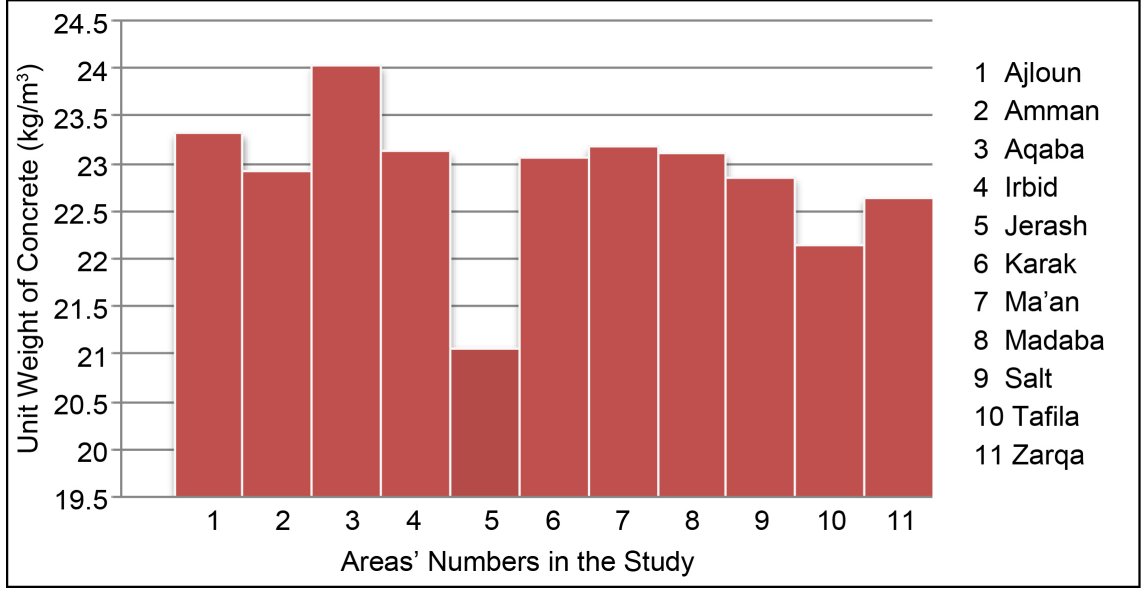

Figure 5. Unit weight of concrete for aggregate from areas in Jordan.

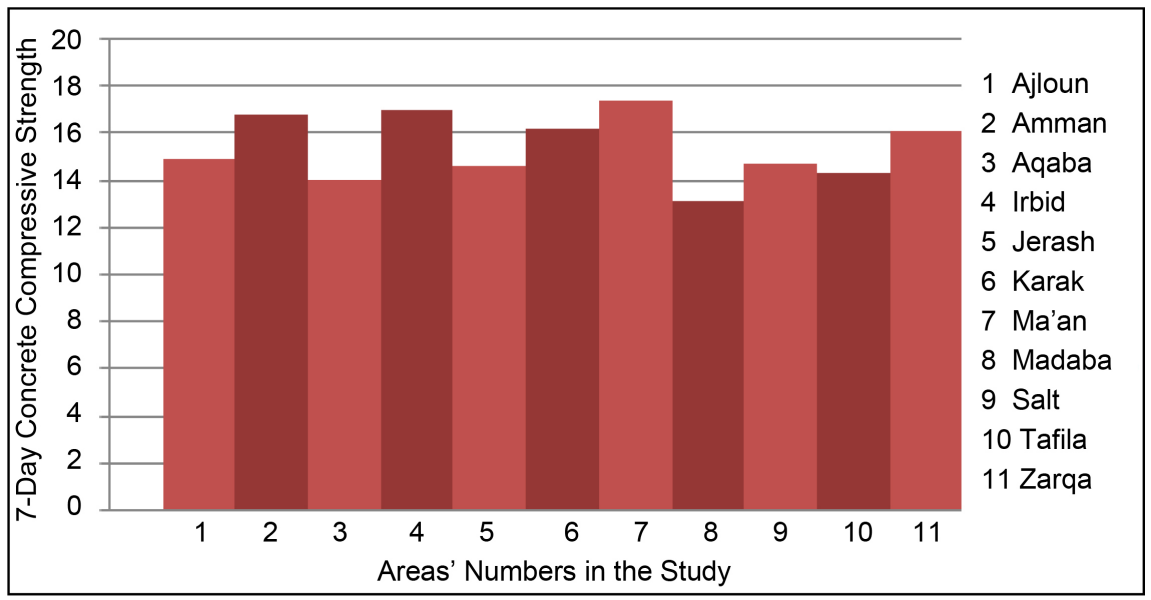

Figure 6. The 7-day compressive strength of areas in Jordan.

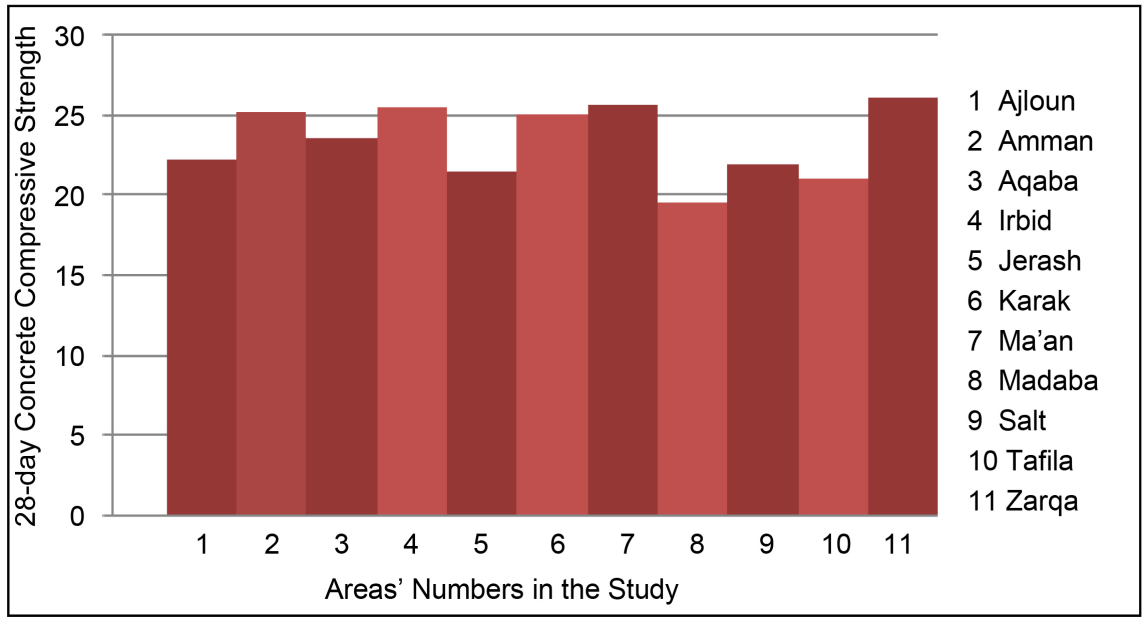

Figure 7. The 28-day compressive strength of areas in Jordan.

respectively. It is expected that the compressive strength will be higher for lower values of abrasion in aggregate. 


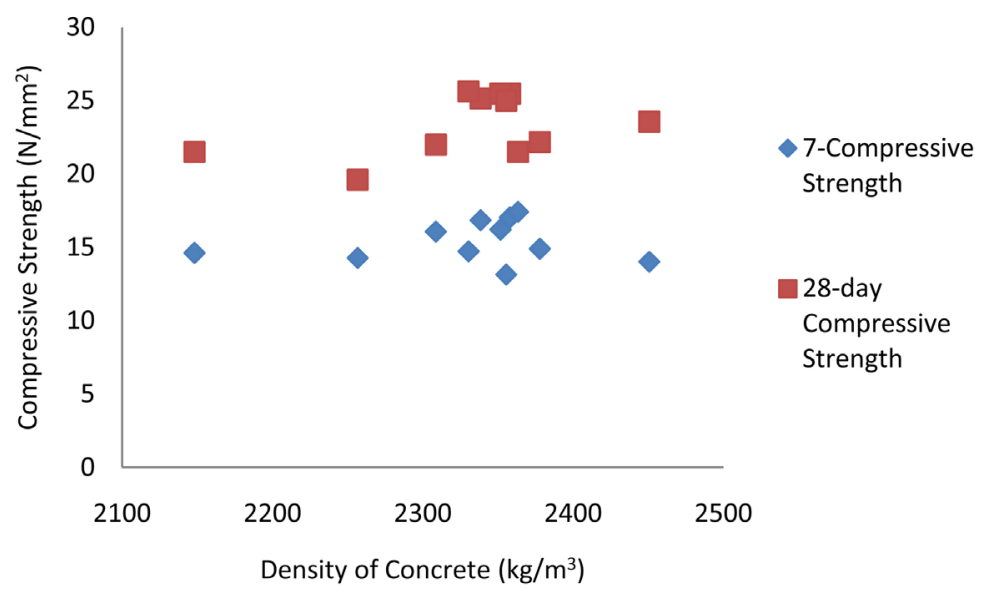

Figure 8. The compressive strength (7- and 28-day) versus the density of concrete.

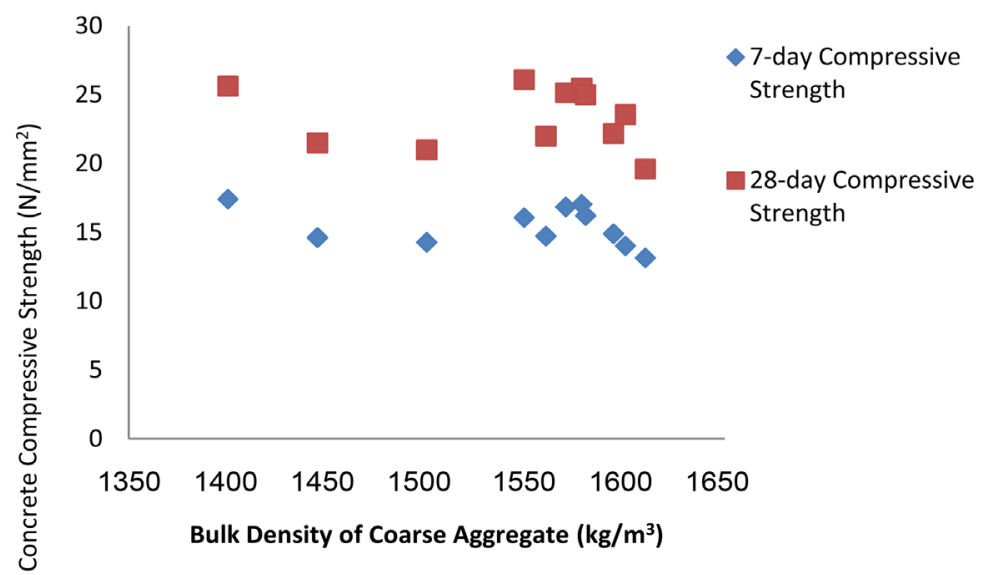

Figure 9. Compressive strength versus bulk density of coarse aggregate.

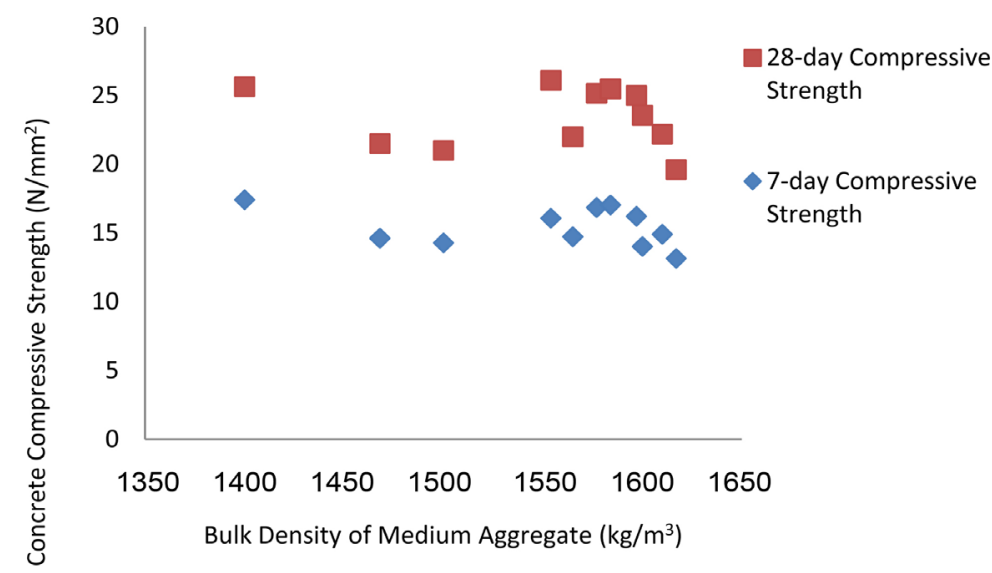

Figure 10. Compressive strength versus bulk density of medium aggregate.

\section{Discussion}

In the current research, physical properties of aggregates were studied and determined. Aggregate properties included specific gravity, bulk density, absorption, 


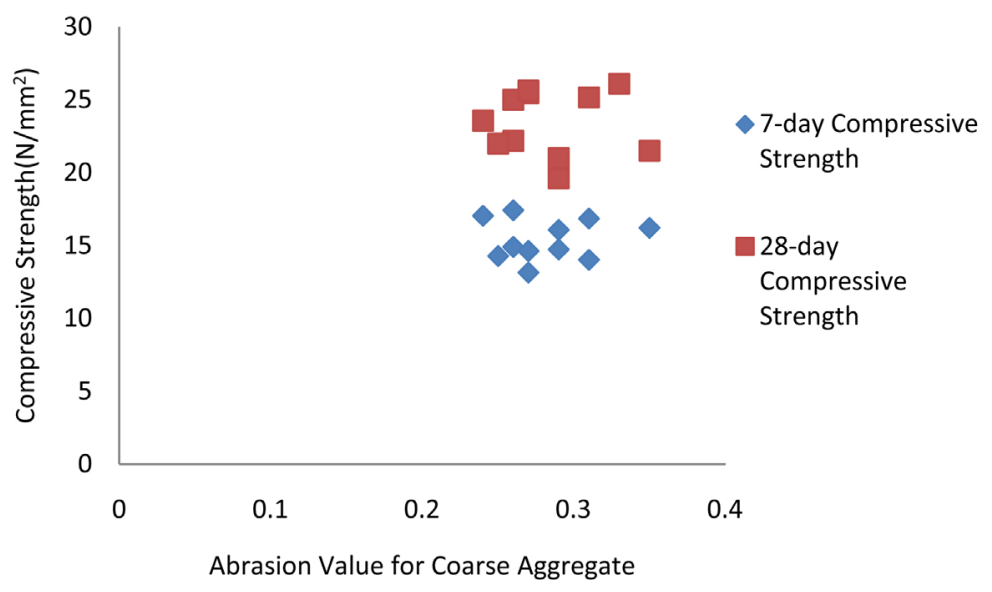

Figure 11. Compressive strength of concrete versus the abrasion value of coarse aggregate.

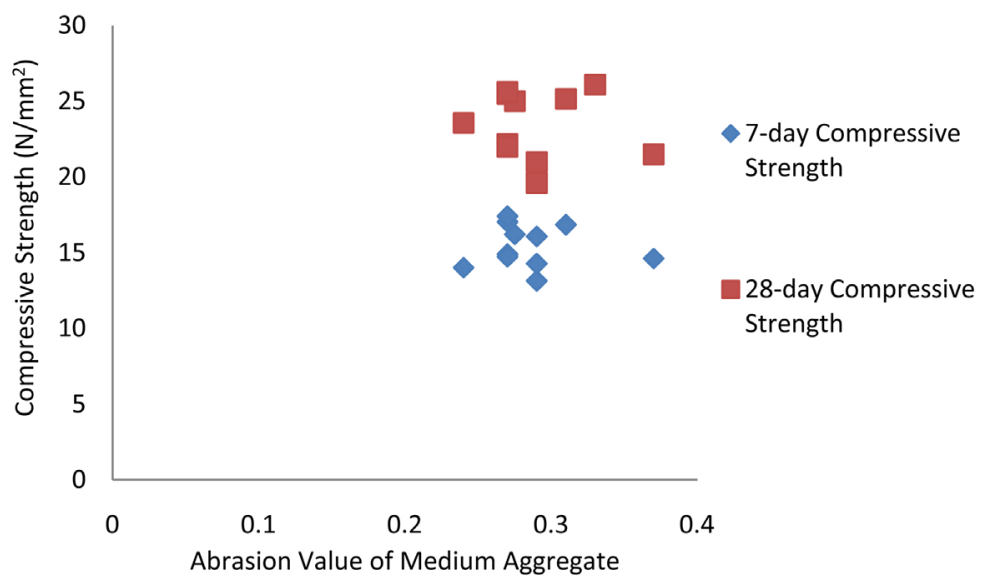

Figure 12. Compressive strength of concrete versus the abrasion value of medium aggregate.

and abrasion. Aggregate from Ma'an, Aqaba, and Ajloun areas have the highest values of specific gravity respectively, while Tafila, Zarqa, Amman and Salt have the lowest values for specific gravity. For bulk density, aggregates from $\mathrm{Ma}$ 'an, Aqaba, and Karak areas have the highest values, while aggregates from Tafila, Salt, and Madaba have the lowest values of bulk density. For absorption, Ajloun, Salt, and Zarqa are the highest three areas of $2.4 \%$ of absorption, while Aqaba, Madaba, and Irbid are the least in absorption of about $1 \%$. For abrasion, Amman, Jerash, and Zarqa areas are the highest, while Ajloun, Karak, and Salt areas are the lowest in abrasion values. For compressive strength at 7-day age of concrete, concrete made from Ma'an, Irbid, Amman, and Zarqa aggregate have the highest values. Also, similar samples in addition to Karak aggregate have highest values for compressive strength at 28 -day age.

\section{Conclusions}

After conducting the study and analyzing the results, many of the findings and 
conclusions can be made:

1) The aggregate in Jordan has different properties following the source for that aggregate.

2) Aggregate from South area of Jordan has the highest value of specific gravity such as Aqaba, Karak, and Ma'an. And aggregate from the middle and North areas of Jordan has less value of specific gravity respectively.

3) Madaba, Ma'an, Aqaba, and Aloun areas have the highest value of bulk density, while other areas in Jordan have less value of bulk density.

4) Madaba, Ma'an, Aqaba, and Ajloun have the least value in absorption, while other areas in Jordan have higher values of absorption.

5) Also, for abrasion; Madaba, Ma'an, and Aqaba have less value in abrasion compared to other areas in Jordan.

6) For bulk density of the concrete, Aqaba has $\left(2450.51 \mathrm{~kg} / \mathrm{m}^{3}\right)$, Ajloun has $\left(2377.78 \mathrm{~kg} / \mathrm{m}^{3}\right)$, and Ma'an has $\left(2363.21 \mathrm{~kg} / \mathrm{m}^{3}\right)$ which are the heaviest densities in the study, respectively. While, Zarqa has $\left(2308.6 \mathrm{~kg} / \mathrm{m}^{3}\right)$, Tafila has $(2256.65$ $\left.\mathrm{kg} / \mathrm{m}^{3}\right)$, and Jerash has $\left(2148.15 \mathrm{~kg} / \mathrm{m}^{3}\right)$ which are the lightest densities of concrete samples respectively.

7) Also, for unit weight of concrete; Aqaba has $\left(24.04 \mathrm{kN} / \mathrm{m}^{3}\right)$, Ajloun has $\left(23.33 \mathrm{kN} / \mathrm{m}^{3}\right)$, and $\mathrm{Ma}$ 'an has $\left(23.07 \mathrm{kN} / \mathrm{m}^{3}\right)$ which are the heaviest unit weights in the current study, respectively. While, Zarqa has $\left(22.65 \mathrm{kN} / \mathrm{m}^{3}\right)$, Tafila has $\left(22.14 \mathrm{kN} / \mathrm{m}^{3}\right)$, and Jerash has $\left(21.07 \mathrm{kN} / \mathrm{m}^{3}\right)$ which are the lightest unit weights of concrete samples respectively.

8) For 7-day compressive strength; Ma'an $\left(17.42 \mathrm{~N} / \mathrm{mm}^{2}\right)$, Irbid (17.04 $\left.\mathrm{N} / \mathrm{mm}^{2}\right)$, and Amman $\left(16.85 \mathrm{~N} / \mathrm{mm}^{2}\right)$ are the highest and give early concrete compressive strength, while Madaba has got $\left(13.14 \mathrm{~N} / \mathrm{mm}^{2}\right)$, Jerash has got $\left(14.62 \mathrm{~N} / \mathrm{mm}^{2}\right)$, and Tafila has got $\left(14.28 \mathrm{~N} / \mathrm{mm}^{2}\right)$. And they are all acceptable because they have achieved more than $67 \%$ of the 28 -day compressive strength of concrete for the same samples. So, concrete made from aggregate of Ma'an, Amman, and Irbid has the highest value in compressive strength at 7-day age and can get the 28-day target of compressive strength.

9) For the 28-day compressive strength as it is expected; Zarqa has got (26.09 $\left.\mathrm{N} / \mathrm{mm}^{2}\right)$, Ma'an has got $\left(25.62 \mathrm{~N} / \mathrm{mm}^{2}\right)$, and Irbid has got $\left(25.47 \mathrm{~N} / \mathrm{mm}^{2}\right)$ are the highest, and they give early compressive strength of concrete, while Madaba has got $\left(19.61 \mathrm{~N} / \mathrm{mm}^{2}\right)$, Tafila has got $\left(21 \mathrm{~N} / \mathrm{mm}^{2}\right)$, Jerash has got $\left(21.5 \mathrm{~N} / \mathrm{mm}^{2}\right)$, and Salt has got $\left(22 \mathrm{~N} / \mathrm{mm}^{2}\right)$, they are the least and they give late compressive strength of the concrete.

10) Bulk density of coarse and medium aggregates and density of concrete affect the compressive strength of concrete in a positive manner; as the density of materials is increased, the compressive strength increases.

11) Also, as the abrasion of materials decrease (coarse and medium aggregates), the compressive strength of concrete increases.

12) And the low absorption of water in aggregates will give high quality concrete (because of sound aggregate). 
The use of high quality materials such as low abrasion and absorption materials (aggregate) will increase the compressive strength of concrete. But factors should be considered also such as the cost of grinding and preparation of sound and strong rocks, and the transmission cost will be high to bring high quality aggregates from other mining further sites to a local site. But, the use of normal concrete strength made by local aggregate can achieve the minimum requirements for strength (ex. Compressive strength).

\section{Conflicts of Interest}

The authors declare no conflicts of interest regarding the publication of this paper.

\section{References}

[1] U.S. Department of Transportation (2004) Transportation Applications of Recycled Concrete Aggregate-FHWA State of the Practice National Review. Federal Highway Administration, Washington DC, 1-47.

[2] Yahya, G. (2017) Aggregates in Concrete Mix Design. Academic Thesis, Luleå University of Technology, Luleå, Sweden.

[3] Shaker, F., Rashad, A. and Allam, M. (2017) Properties of Concrete Incorporating Locally Produced Portland Limestone Cement. Ain Shams Engineering Journal, 9, 2301-2309.

[4] Livesey, P. (1999) Performance of Limestone-Filled Cements. Proceedings International Conference on Blended Cements in Construction, Sheffield, UK, 1999.

[5] Alexander, M. and Mindess, S. (2005) Aggregates in Concrete. Taylor and Francis Group, Milton Park, Oxfordshire, UK.

[6] Kwan, A.K.H. and Mora, C.F. (2002) Effects of Various, Shape Parameters on Packing of Aggregate Particles. Magazine of concrete Research, 53, 91-100.

https://doi.org/10.1680/macr.2001.53.2.91

[7] Claus, P. and Nyholm, T.L. (2009) User's Manual, Packing. Concrete Center, Danish Technological Institute, Denmark.

[8] Smeplass, S. (2000) BE96-3942/R12 Applicability of the Particle-Matrix Model to LWAC. Euro Light Concrete, Brussels.

[9] Reknes, K. (2001) Particle-Matrix Model Based Design of Self-Compacting Concretewith Lignosulfonate Water Reducer. Proceedings of the Second International Symposium on Self-Compacting Concrete, Tokyo, Japan, 2001, 247-256.

[10] Bartos, P.J., Cleland, D.J., and Marrs, D.L. (2004) Production Methods and Workability of Concrete (Vol. 32). CRC Press, Boca Raton, FL.

[11] Samarakoon, S., Vie, Ø.S. and Fjelldal, R.K. (2015) Self-Compacting White Concrete MixDesign Using the Particle Matrix Model. International Journal of Civil, Environmental, Structural, Construction and Architectural Engineering, 9, 802-806.

[12] Chateauneuf, A., Niyigena, C. and Amziane, S. (2016) Chapter 2: Investigating of Hemp Concrete Mechanical Properties Variability Due to Hemp Particles. Mechanics of Composite and Multi-functional Materials, Volume 7, Proceedings of the 2016 Annual Conference on Experimental and Applied Mechanics.

[13] Fatma, S., Ahmed, R. and Mohamed, A. (2017) Properties of Concrete Incorporating Locally Produced Portland Limestone Cement. Ain Shams Engineering Journal, 
9, in press.

[14] BS EN1097-6:2013 Tests for Mechanical and Physical Properties of Aggregates. Determination of Particle Density and Water Absorption.

[15] BS EN 1097-3:1998 Tests for Mechanical and Physical Properties of Aggregates. Determination of Loose Bulk Density and Voids (British Standard).

[16] BS EN 1097-3:1998 Testing Aggregates. Methods for Determination of Density.

[17] BS 812:2, EN 12390-7, Test Method for Density, Relative Density (Specific Gravity), and Absorption of Fine Aggregate.

[18] BS EN 1097-6:2013 Tests for Mechanical and Physical Properties of Aggregates. Determination of Particle Density and Water Absorption.

[19] BS 812-103.1:1985 Method for Determination of Particle Size Distribution-Sieve Tests.

[20] BS 812-1985 and ASTM C136-14 Mechanical Properties of Aggregate, Sieve Analysis.

[21] BS 1881: Part 108: 1983 Method for Making Test Cubes from Fresh Concrete.

[22] BS 1881: Part 107: 1983 Method for Determination of Density of Compacted Concrete.

[23] Mirjana, M., Vlastimir, R. and Snežana, M. (2011) Recycled Concrete as Aggregate for Structural Concrete Production. Sustainability, 3, 465-468. https://doi.org/10.3390/su2051204

[24] Al-Jabri, K.S., Al-Saidy, A.H., Taha, R. and Al-Kemyani, A.J. (2011) Effect of Using Wastewater on the Properties of High Strength Concrete. Procedia Engineering, 14, 370-376. https://doi.org/10.1016/j.proeng.2011.07.046

[25] Sarireh, M. (2015) Concrete Mix Construction Using Local Materials in Karak and Tafila Area. International Conference for Capacity Building and Poverty Alleviation and Development, American University, Dubai, 26-28 May 2015, 470-476.

[26] British DOE (Department of Environment) Method (1988) Design of Normal Concrete Mixes. British Standards Institution, London.

[27] BS EN 12350-2:2009 Testing Fresh Concrete. Slump-Test.

[28] BS 882: 1992 Specification for Aggregates from Natural Resources for Concrete.

[29] General Specifications for Civil Engineering Works, Section 16, Concrete and Joints in Concrete.

http://www.cedd.gov.hk/eng/publications/standards_handbooks_cost/doc/stan_gs_ 2006/gs_20006_doc/Section_16_2006Edition_Concrete_26Feb07.pdf

[30] BS-EN12390-1 Testing Hardened Concrete-Part 1: Shape, Dimensions and Other Requirements of Specimens and Molds. British Standard Institution, 2002.

[31] Ghrair, A.M., Al-Mashaqbeh, O.A., Sarireh, M.K., Al-Kouz, N., Farfouraa, M. and Megdal, S.B. (2016) Influence of Grey Water on Physical and Mechanical Properties of Mortarand Concrete Mixes. Ain Shams Engineering Journal, 3, 56-61.

[32] BS-EN12390-3 Testing Hardened Concrete-Part 3: Compressive Strength of Test Specimens. British Standard Institution, 2002, 1-18.

[33] BS 8500-2:2002 Concrete-Complementary British Standard to BS EN206-1 Part 2 Specifications for Constituent Materials and Concrete. British Standards Institution, London. 